\title{
INVESTIGATION OF THE PHOTOMETRIC SYSTEM OF THE METEOR TV CCD CAMERAS
}

\author{
Kulichenko M.O. ${ }^{1}$, Maigurova N.V. ${ }^{2}$, Shulga O.V. ${ }^{3}$ \\ Research Institute "Mykolaiv Astronomical Observatory", Ukraine \\ 1'niiko4kulichenko@gmail.com, ${ }^{2}$ nadija@nao.nikolaev.ua, ${ }^{3}$ shulga-av@ukr.net
}

\begin{abstract}
The study of meteoroids and the phenomena arising from their entry into the Earth's atmosphere is of considerable scientific and practical interest to obtain data on the origin and evolution of the solar system, to study the physics of planetary atmospheres, and to solve the problem of problem of asteroid-cometary-meteoroid hazard. Today the most effective and informative are photometric and spectral studies of meteor phenomena, which provide information on the chemical composition and physical properties (density, combustion temperature, etc.) of meteoroids that allow us to classify these bodies by parental origin and mineralogical structure. This paper presents the results of a study of the photometric system of eight meteor telescopes of the same type with a lens having a wide field of view ( $f=50 \mathrm{~mm}, \mathrm{f}$ / 1.2) and WAT-902H 2 cameras. Telescopes equipped with broadband Cokin filters P050 (cyan) and P003 in the blue and red bands are installed in Mykolaiv and Odesa. An original method is used to observe meteors - the method of accumulation of shifted frames for TV cameras, which provide an accumulated image of reference stars in the form of points on a motionless telescope. In this work, simultaneous observations of reference stars in two filters obtained on 2 different observation nights were used. Cross-identification of the observational data with the Gaia DR2 catalog showed that the standard error of the residual coordinate differences (Obs - Gaia DR2) is about 7 "for both coordinates in both filters. The bandwidths of our filters are closest to the photometric system Gaia BP / RP, which was selected as a standard system to which the obtained instrumental stellar magnitudes were transformed. Transformation coefficients for converting instrumental stellar magnitudes into Gaia BP/RP photometric system were obtained by linear regression. Average standard photometric solution errors were $0.2^{\mathrm{mag}}$ and $0.3^{\mathrm{mag}}$ for red $\mathrm{d}^{\mathrm{i}}$ and blue band, respectively. The possibility of determining the color index based on the array of common stars from observations in two bands is shown.
\end{abstract}

Keywords: Meteors, photometry, Gaia BP/RP photometric system, color index.

АНОТАЦІЯ. Вивчення метеороїдів та явищ, що виникають внаслідок їх входження в атмосферу Землі, має значний науковий та практичний інтерес для отримання даних про походження та еволюцію Сонячної системи, вивчення фізики планетних атмосфер, а також для вирішення проблеми астероїдно- метеороїдної безпеки. Найбільш ефективними й інформативними на сьогоднішній день $є$ фотометричні та спектральні дослідження метеорних явищ, які дозволяють отримати інформацію про хімічний склад і фізичні властивості (щільність, температуру згоряння тощо) метеороїдів, а відповідно і класифікувати ці тіла за походженням батьківських тіл і мінералогічною структурою. Ця робота представляє результати дослідження фотометричної системи восьми метеорних телескопів одного типу з об'єктивом, що має широке поле зору (f=50 мм, f/1,2) та камерами WAT902Н2. Телескопи, оснащені широкосмуговими Cokin фільтрами у червоному(Р003) та синьому (Р050) діапазонах, встановлені у Миколаєві та Одесі. Для спостережень метеорів використовується оригінальний метод - метод накопичення кадрів зі зсувом для ТВ камер, які забезпечують отримання накопиченого зображення опорних зірок у вигляді точок на нерухомому телескопі. $\mathrm{y}$ даній роботі були використані одночасні спостереження опорних зірок в двох фільтрах, отримані в 2 різні ночі спостережень. Виконана крос-ідентифікація отриманих даних 3 каталогом Gaia DR2 показала, що середньоквадратична помилка остаточних різниць координат (Obs - Gaia DR2) становить близько 7" для обох координат в обох фільтрах. Смуги пропускання наших фільтрів найбільш близькі до фотометричної системи Gaia $\mathrm{BP} / \mathrm{RP}$, яка була обрана в якості стандартної системи, до якої було переведено отримані інструментальні зоряні величини. Коефіцієнти перетворення для переведення інструментальних значень величин у фотометричну систему Gaia BP/RP отримані методом лінійної регресії. Середні стандартні похибки фотометричного розв'язку склали $0.2 \mathrm{mag}$ та $0.3^{\mathrm{mag}}$ відповідно для червоного та синього діапазонів. Показано можливість визначення показника кольору на основі сформованого масиву спільних зірок зі спостережень у двох смугах.

Ключові слова: Метеори, фотометрія, Gaia BP/RP фотометрична система, кольоровий показник.

\section{Introduction}

Photometric studies can be effective and informative means to obtaining information about the chemical 
composition and physical properties of the target bodies. But in order to use and compare the data obtained by different scientists at different times, it is required to measure magnitudes to a standard internationally agreed system with good precision. The most studied and widespread in this respect is the UBVRI Johnson - Cousins system, in which a large amount of astronomical data has been accumulated. Unfortunately, there are a number of difficulties for the mass reproduction of this system, associated both with the availability of filters and with a limited number of standard stars for performing photometric reductions. Gaia DR2 was released in April 2018 and contains a photometric catalogue of more than 1 billion sources over all celestial sphere. This release contains color information in the form of integrated BP and RP photometry in addition to the latest G-band photometry (Riello et al., 2018). This is full-sky survey with the unprecedented spatial resolution, high accuracy could use for the purpose of photometric calibration for wide range of astronomical tasks.

\section{Instrumental system}

Four pairs of meteor telescopes equipped with TV CCD cameras WAT-902H2 and lens with focal length $50 \mathrm{~mm}$ (f/1.2) are located at RI «MAO» (2 pairs), Vitovka (1 pair, $12 \mathrm{~km}$ baseline) and Kryzhanivka (1 pair, $100 \mathrm{~km}$ baseline). First results obtained with these telescopes are described in Kulichenko et al., 2019. Telescopes equipped with broadband Cokin filters P050 (cyan) and P003 (red) hereinafter referred to as blue and red bands. Observations are provided using track-and-stack technique for obtaining frames with reference stars (Kulichenko et al., 2015). Cameras work in the interlace mode (50 fps) and number of accumulated frames is $500(10 \mathrm{~s})$.

\section{Astrometric Reductions and Accuracy}

Processing of obtained observations included next steps:

1) Frames filtering using software for processing of the CCD images developed in RI "MAO";

2) Extracting stars and cross-match with catalog Tycho-2 for obtaining reduction coefficients using Astrometry.net software (Lang et al., 2010). Brightness of extracted stars in ADU with subtracted background also saved in result files;

3) Obtaining a summary csv-table for all detected stars with measured celestial coordinates and streams from all processed frames using a Python script developed at the Research Institute "MAO". The table also includes coordinates and magnitudes from Tycho- 2 catalogs for all stars.

In this study, further results and calculations were obtained on the basis of arrays of simultaneous observations of stars for two evenings (2018/11/08 and 2018/11/09) in P050 (BLUE) and P003 (RED) bands.

The obtained observational arrays were cross matching with Gaia DR2 catalog to estimate positional accuracy. The standard deviations of the residual coordinate differences (Obs - Gaia DR2) in right ascension and declination were used as an estimate of the accuracy of the observations. Cross match procedures was made by TOPCAT software (Taylor M., 2005) with 30" match radius parameters. The results of cross matching are shown in Table 1. (Obs - Gaia DR2) differences and their standard deviations in right ascension and declination are given in column $3, \mathrm{~N}$ - number of stars. Differences in right ascension include cos DE.

As you can see from the table, there are no significant systematic differences between obtained coordinates and Gaia DR2 catalog. The accuracy is almost the same for both coordinates in the blue and red ranges.

Table 1: Results of cross matching between observational arrays and Gaia DR2 catalog

\begin{tabular}{|c|c|c|c|c|}
\hline Data & \multirow{2}{*}{ Band } & \multicolumn{2}{|c|}{ (Obs - Gaia DR2) } & \multirow{2}{*}{ N } \\
\cline { 3 - 4 } & & RA, arcsec & DE, arcsec & \\
\hline $11 / 08$ & Blue & $-0.7 \pm 6.8$ & $-0.5 \pm 6.6$ & 6490 \\
\hline $11 / 08$ & Red & $0.5 \pm 6.9$ & $0.0 \pm 6.6$ & 1925 \\
\hline $11 / 09$ & Blue & $-0.5 \pm 6.9$ & $-0.5 \pm 6.7$ & 1647 \\
\hline $11 / 09$ & Red & $-0.2 \pm 6.7$ & $0.2 \pm 6.7$ & 1530 \\
\hline
\end{tabular}

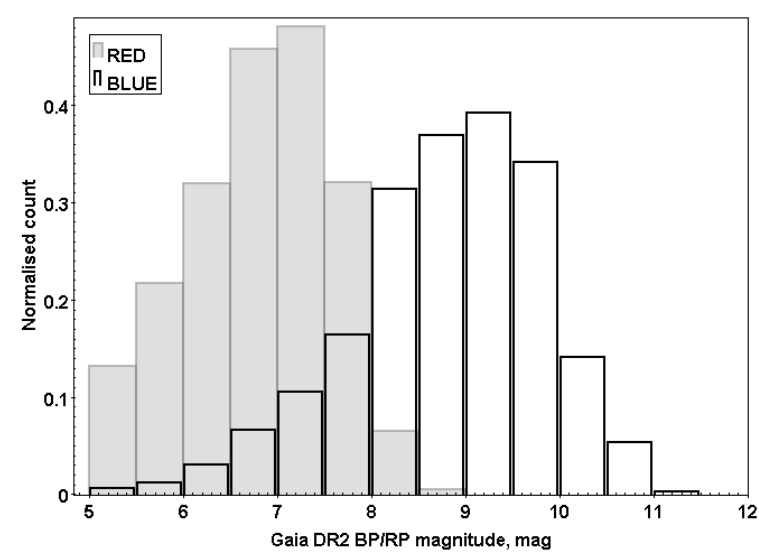

Figure 1: Histogram distribution in BP and RP Gaia DR2 magnitudes.

The histogram of distribution in BP Gaia DR2 magnitude for observational array with blue filter and RP Gaia DR2 magnitude for observational array with red filter is presented in Fig. 1. The difference in penetration for the two bands is associated with the higher sensitivity of WAT$902 \mathrm{H} 2$ camera in the blue region.

\section{Photometric reductions}

The brightness measurements of stars in the CCD images were carried out using built-in source extractor of the Astrometry.net software. The counts from the stars with the subtracted background were converted to the scale of instrumental magnitudes according to the known ratio:

$$
M i=-2.5 \lg (F \operatorname{lu} x)
$$

The brightness correction for the relative change in the air mass in the frame field of view was not made here. Since the Cokin P050 (cyan) and P003 (red) filters have wide bandwidths, Gaia DR2 BP/RP photometric system has been selected as the standard system. The relationship between magnitudes and color index in these systems can be represented in the form (Hardy, 1967): 

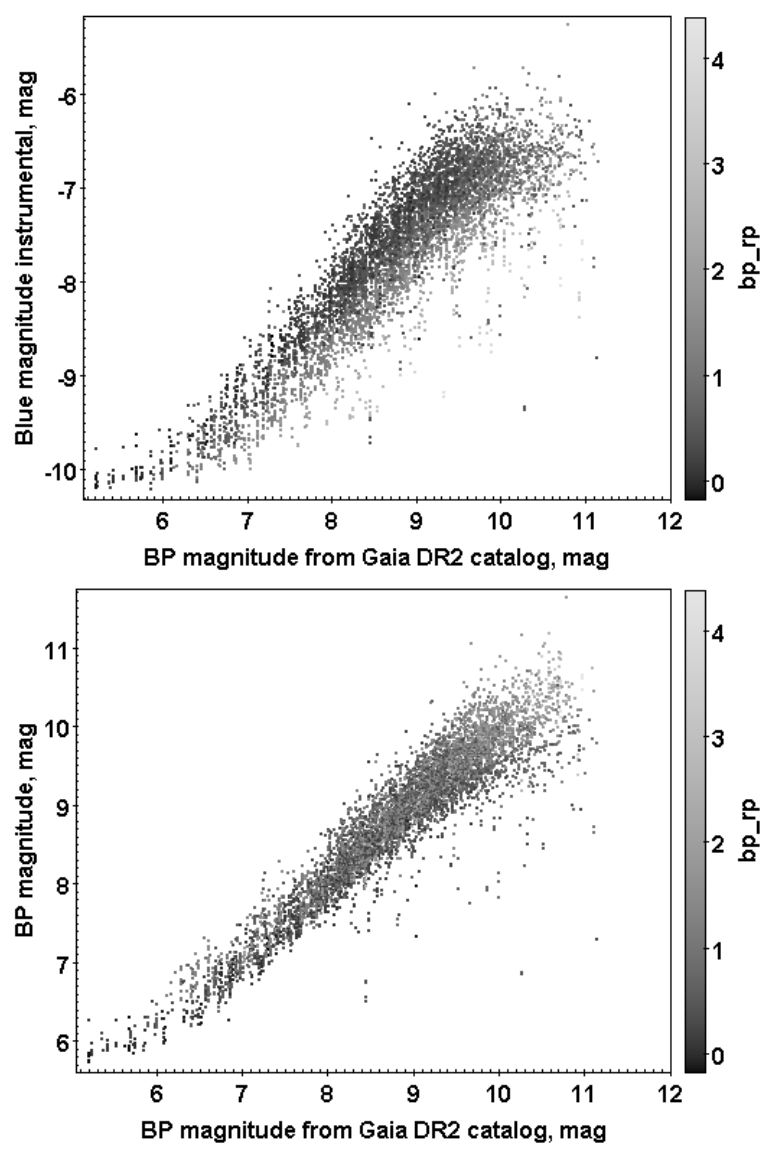

Figure 2: Relation between instrumental and standard magnitudes for observations in blue range, up - before transformation, down - after transformation.

$$
\begin{aligned}
M a g_{\text {Gaia }}^{i}= & a 1 \times M a g_{\text {Instr }}^{i}+a 2 \times(B P-R P)_{\text {Gaia }}^{i}+M_{0}^{i}, \\
& (B P-R P)_{\text {Gaia }}^{i}=a 3 \times C_{\text {Instr }}^{i}+C_{0}^{i}
\end{aligned}
$$

where $M a g_{\text {Gaia }}^{i},(B P-R P)_{\text {Gaia }}^{i}$ - catalog values of star magnitude and color index, $\mathrm{Mag}_{\text {Instr }}^{i}, C_{\text {Instr }}^{i}$ - observational values of star magnitudes and color indices, a1, a2, a3 transformation coefficients, $M_{0}^{i}, C_{0}^{i}$ - zero point constant.

The transformation coefficients were found by the least squares method. The solution was carried out by the method of fixed-point iteration using the 3-sigma criterion. The calculated values of transformation star coefficients and their errors are presented in Table 2.

Table 2: Transformation coefficients (star magnitude)

\begin{tabular}{|l|c|l|l|l|l|}
\hline & $\boldsymbol{a 1}$ & $\mathbf{a 2}$ & $\boldsymbol{M}_{\boldsymbol{0}}$ & $\mathrm{SD}$ & $\mathrm{N}$ \\
\hline $\mathrm{B}$ & $0.980 \pm 0.004$ & $0.504 \pm 0.004$ & $15.84 \pm 0.03$ & 0.25 & 7684 \\
\hline $\mathrm{R}$ & $0.938 \pm 0.005$ & $-0.215 \pm 0.004$ & $14.08 \pm 0.04$ & 0.21 & 3302 \\
\hline
\end{tabular}

The Fig. 2 presents correlation between instrumental and Gaia DR2 magnitudes before and after recalculation of the instrumental magnitudes.

As could be seen from table 2 the accuracy of link between the two systems is $0.25^{\mathrm{mag}}$ in blue band and $0.21^{\mathrm{mag}}$ in red band.
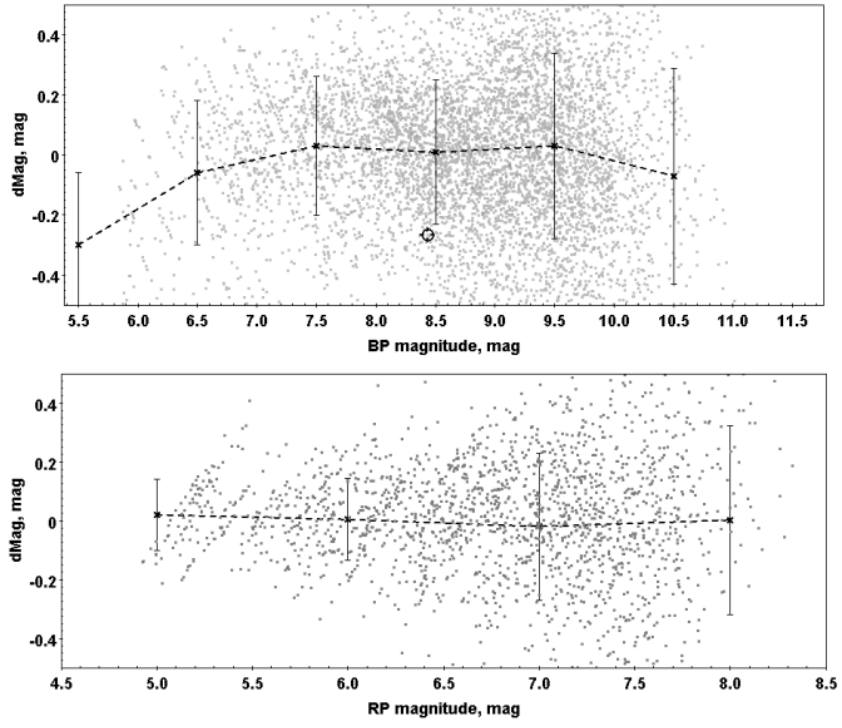

Figure 3: Residual differences between instrumental and standard magnitudes vs standard magnitude from Gaia DR2 catalog.

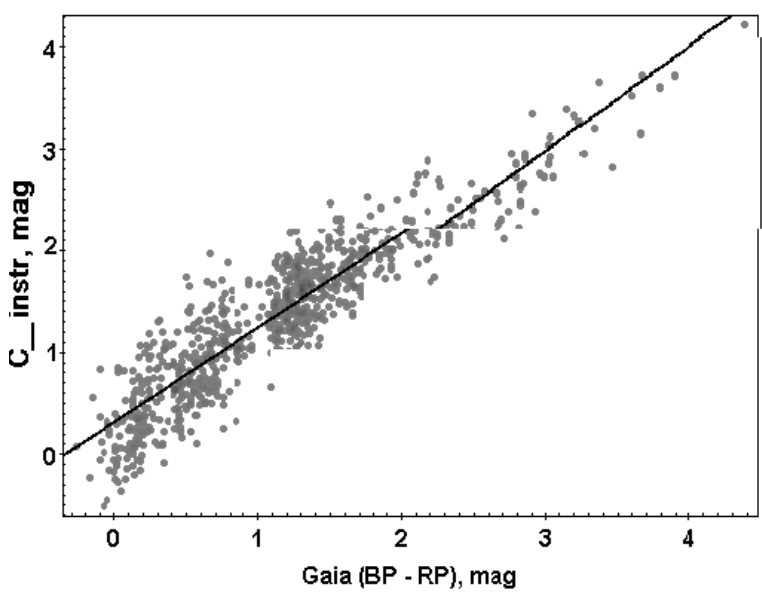

Figure 4: Relation between instrumental and standard (Gaia DR2) color indexes

Relation between residual differences between standard and instrumental magnitudes is presented in Fig. 3. The figure shows the absence of significant systematic differences in magnitudes in the observational range. The random error is determined by the errors of the least squares method solution.

To calculate the color relation, the observational arrays are cross-matched to find common stars in the blue and red bands.The coefficients were found by the least squares method, similar to the scheme for determining the transformation coefficients for the star magnitudes. The most widely used color characteristic of astronomical objects is $(\mathrm{B}-\mathrm{V})$. The values $(\mathrm{B}-\mathrm{V})$ for our stars were selected from APASS DR9 catalog (Henden et al., 2015). Transformation coefficients between $(\mathrm{B}-\mathrm{V})$ color and instrumental color index also has been calculated. The calculated values of transformation color coefficients and their errors are presented in Table 3 . 
Table 3: Transformation coefficients (color index)

\begin{tabular}{|l|l|c|l|l|}
\hline & $\boldsymbol{a 3}$ & $\boldsymbol{C}_{\mathbf{0}}^{\boldsymbol{i}}$ & $\boldsymbol{S D}$ & $\boldsymbol{N}$ \\
\hline $\mathrm{BP}-\mathrm{RP}$ & $0.88 \pm 0.01$ & $-0.08 \pm 0.02$ & 0.28 & 855 \\
\hline $\mathrm{B}-\mathrm{V}$ & $0.69 \pm 0.02$ & $0.06 \pm 0.04$ & 0.32 & 265 \\
\hline
\end{tabular}

The obtained data show the possibility to estimate of the meteors color from the observations at the meteor telescopes equipped filters in two bands.

\section{Conclusion}

The transformation coefficients to link the instrumental values of magnitudes and color indexes of the meteor complex telescopes to the Gaia BP/RP photometric system were calculated.
The mean standard errors of the photometric solution are $0.25^{\mathrm{mag}}$ and $0.21^{\mathrm{mag}}$ for BP and RP ranges, respectively. The possibility of color index determinations based on reference stars observations with red and blue broadband filters is shown.

Acknowledgements. This research has made use of the VizieR catalogue access tool, CDS, Strasbourg, France.

\section{References:}

Hardy X.: 1967, Astronomical Techniques ed.by W.A. Hiltner, 536.

Henden A. et al.: 2015, ASS, 336, 16.

Kulichenko N. et al.: 2015, WGN, 43(3), 81.

Kulichenko M.O. et al.: 2019, OAP, 32, 165.

Lang D. et al.: 2010, $A J, 137,1782$.

Riello M. et al.: 2018, $A \& A, \mathbf{6 1 6}, \mathrm{A} 3$.

Taylor M.: 2005, ASP Conf. Ser., 347, 29. 